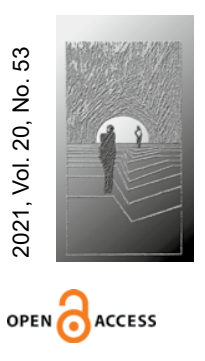

Barbara Jankowiak

http://orcid.org/0000-0002-7660-2070 Uniwersytet im. Adama Mickiewicza w Poznaniu barbara.jankowiak@amu.edu.pl

Sylwia Jaskulska

https://orcid.org/0000-0002-3454-7894 Uniwersytet im. Adama Mickiewicza w Poznaniu sylwia.jaskulska@amu.edu.pl DOI: 10.35765/hw.1966

\title{
Dobrostan nauczycielek i nauczycieli wychowania przedszkolnego a ich postawy wobec kształcenia na odległość w czasie pandemii COVID-19
}

\section{STRESZCZENIE}

CEL NAUKOWY: Eksploracja zależności pomiędzy dobrostanem nauczycielek/li wychowania przedszkolnego a ich postawami wobec kształcenia na odległość w czasie pandemii COVID-19.

PROBLEM I METODY BADAWCZE: Użyto testu t Studenta dla prób zależnych do porównywania dwóch średnich pochodzących z jednej grupy: średniej wyniku w skali postaw oraz średniej skali psychospołecznego prosperowania. Do badań kwalifikowane/ni były/li nauczycielki/le wychowania przedszkolnego prowadzący zajęcia zdalne (427 kobiet i 2 mężczyzn).

PROCES WYWODU: W tekście zaprezentowano podstawy teoretyczne badań, metody, przebieg badań oraz wyniki $z$ interpretacjami.

WYNIKI ANALIZY NAUKOWEJ: Uzyskano wyniki świadczące o tym, że im wyższy poziom dobrostanu, tym lepiej nauczycielki i nauczyciele oceniają poszczególne elementy ich rzeczywistości w czasie edukacji zdalnej. Wysoki dobrostan jest związany z dostrzeganiem możliwości wspierania fizycznego, emocjonalnego, poznawczego i społecznego rozwoju dziecka, rzutuje na odczuwanie mniejszego zakresu trudności związanych z kształceniem zdalnym (lub skuteczniejszego ich pokonywania), pozwala dostrzec rozwój własnych kompetencji zawodowych, ma związek z częstszym wykorzystywaniem elementów kształcenia zdalnego w przeszłości i planowaniem wykorzystania go w przyszłości, a także odczuwaniem pozytywnych emocji w relacjach z ludźmi, którzy wraz z nauczycielkami tworzą społeczność danego przedszkola.

WNIOSKI, INNOWACJE, REKOMENDACJE: Rekomendacje dotyczą wzmacniania zawodu nauczyciela wychowania przedszkolnego poprzez wykorzystywanie osobistych zasobów nauczycielek/li do kreowania środowiska pracy.

$\rightarrow$ SŁOWA KLUCZOWE: DOBROSTAN, NAUCZYCIEL WYCHOWANIA PRZEDSZKOLNEGO, KSZTALCENIE NA ODLEGŁOŚĆ, COVID-19 


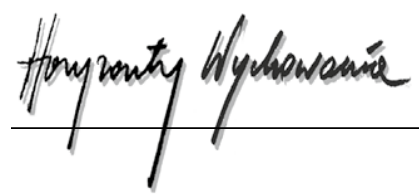

ABSTRACT

Pre-school Teacher's Well-being and Their Attitudes Towards Distance Education During the COVID-19

RESEARCH OBJECTIVE: To explore the association between the well-being of pre-school teachers and their attitudes towards distance education during the COVID-19 outbreak.

THE RESEARCH PROBLEM AND METHODS: The results were submitted to statistical analysis using the Student T-test for dependent groups. A test was used to compare the mean score on the attitude scale and the mean scale of psychosocial well-being. Pre-school teachers, who were conducted remote classes ( 427 women and 2 men) were qualified for the research.

THE PROCESS OF ARGUMENTATION: The text presents the theoretical background of the research, methods, and research results with interpretations.

RESEARCH RESULTS: The results showed that the higher the level of well-being, the better teachers assess elements of their reality during distance education time. High well-being is associated with the perception of the possibility of supporting the child's physical, emotional, cognitive, and social development, it affects the perception of a smaller range of difficulties related to distance education (or overcoming them more effectively), allows noticing the development of one's professional competences is related to the more frequent use of distance learning elements in the past and planning to use it in the future, as well as feeling positive emotions in relationships with people who, together with teachers, create the pre-school communities.

CONCLUSIONS, INNOVATIONS, AND RECOMMENDATIONS: The recommendations concern strengthening the profession of pre-school teachers by using their own' resources to create a work environment.

\section{$\rightarrow$ KEYWORDS: WELL-BEING, PRESCHOOL TEACHER, DISTANCE EDUCATION,} COVID-19

\section{Wprowadzenie}

Okres pandemii wirusa SARS-CoV-2 wywołującego chorobę COVID-19 (He i in., 2020) to czas znaczących i nagłych zmian w funkcjonowaniu przedszkoli w Polsce. Zgodnie z Rozporządzeniem Ministra Edukacji Narodowej z dnia 20 marca 2020 r. w sprawie szczególnych rozwiązań w okresie czasowego ograniczenia funkcjonowania jednostek systemu oświaty w związku z zapobieganiem, przeciwdziałaniem i zwalczaniem COVID-19 w marcu 2020 roku wprowadzono w szkołach i przedszkolach kształcenie na odległość. Zmieniło ono całkowicie funkcjonowanie placówek przedszkolnych, które z bezpośredniego kontaktu nauczycielek/li z małymi dziećmi z dnia na dzień wdrożyły różne formy edukacji na odległość. To, co było dotychczas tylko opcją wykorzystywaną raczej w edukacji dorosłych 
i starszych uczniów i uczennic, należało dostosować do pracy z małym dzieckiem. Wielu nauczycieli i nauczycielek do tej pory pracowało, nie używając na co dzień nowoczesnych technologii. Dlatego też wiedzę o istnieniu konkretnych aplikacji i narzędzi umożliwiających komunikację z dziećmi i rodzicami oraz ich praktycznym zastosowaniu musieli zdobywać w zawrotnym tempie w niezwykle stresujących okolicznościach (Zaród, 2020). W debacie publicznej pojawiły się głosy na temat konieczności ochrony nauczycieli i nauczycielek, którzy mogą mieć problemy w dbaniu o równowagę między pracą online i życiem osobistym (Zaród, 2020). Wskazywano także, że konieczność zachowania dystansu społecznego może utrudnić uzyskiwanie wsparcia społecznego uznanego za istotny czynnik wspierający zdrowie psychiczne w sytuacjach kryzysu (Saltzman i in., 2020). Prowadzone badania dotyczące samopoczucia nauczycielek i nauczycieli szkół wskazują, że odczuwają oni stres związany ze zdalnym nauczaniem (Centrum Cyfrowe, 2020), a ich obecne samopoczucie psychiczne oraz fizyczne jest gorsze w porównaniu do czasu sprzed pandemii. Wśród badanych 65,3\% twierdzi, że czuje się psychicznie dużo gorzej lub trochę gorzej, większość odczuwa trudności w zasypianiu, brak energii, zdenerwowanie czy zły nastrój. Nauczyciele mieli także objawy zmęczenia cyfrowego, a z ich deklaracji wynika, że często lub bardzo często pozostawali w ciągłej gotowości do odbierania połączeń i powiadomień $(86,8 \%)$, mieli dość siedzenia przy komputerze $(85,2 \%)$ oraz że czują się przemęczeni i przeładowani informacjami $(76,8 \%)$. Często lub bardzo często wskazywali też na odczuwanie rozdrażnienia z powodu ciągłego używania komputera $(67,1 \%)$, a nawet na potrzebę bycia niedostępnym dla nikogo w sieci (59,3\%) (Ptaszek i in., 2020). Nauczycielki i nauczyciele doświadczają więc trudności i obciążeń związanych ze zmianą sposobu pracy, jednak $z$ drugiej strony badania wykazały, że ich dobrostan psychologiczny (eudajmonistyczny) podczas pandemii jest dość wysoki (Jaskulska i Jankowiak, 2020). Ponadto przytoczone dane dotyczą nauczycielek/li pracujących w szkołach i nie ma do tej pory danych na temat dobrostanu nauczycielek i nauczycieli pracujących z małymi dziećmi w przedszkolach.

Warto podkreślić, że wizerunek nauczycielki/la wychowania przedszkolnego w wielu krajach, w tym także w Polsce, nie jest najlepszy. Przedszkolu przypisuje się funkcję jedynie opiekuńczą, a potoczna nazwa zawodu „przedszkolanka” lokuje tę profesję bliżej systemu zapewniania opieki niż edukacji. Brakuje świadomości wysokich wymagań zawodu. Praca w przedszkolu jest postrzegana jako praca matek, a tej nie traktuje się jako intelektualnej (Alezra, 2019). Gdy mowa o kompetencjach nauczycielki/la przedszkola, na plan pierwszy wysuwa się to, że „lubią" one/oni dzieci. Nauczycielki/le przedszkola rzadko są podmiotem badań, zwykle zalicza się ich do szerszej grupy nauczycieli „edukacji elementarnej” i traktuje marginalnie (Kuszak, 2020).

Trudności wynikające z podejmowanych wyzwań związanych z wdrażaniem zdalnej edukacji mogły być pogłębiane przez ogólnie niski status zawodu i jego nie najlepszy medialny wizerunek. Wiele doniesień medialnych o przedszkolach z okresu edukacji zdalnej związanej z pandemią dotyczyło faktu niemożliwości powrotu rodziców do pracy zawodowej ${ }^{1}$,

${ }^{1}$ https://finanse.wp.pl/koronawirus-rodzice-w-kropce-musza-wrocic-do-pracy-a-przedszkola-i-zlobki-nie-przyjmuja-6539102453889153a (dostęp: 12.09.2020). 


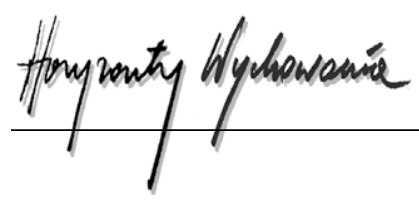

nasilonego nosicielstwa wirusów przez najmłodsze dzieci² ${ }^{2}$ a później, gdy przedszkola były otwierane, także kolejnych ognisk zakażeń w tych placówkach ${ }^{3}$. Informacje te nie były nieprawdziwe, wiele ma umocowanie w prowadzonych w czasie trwania pandemii badaniach naukowych (Heald-Sargent i in., 2020), jednak o ile w odniesieniu do szkół pokazywano też różne podejmowane przez nauczycieli akcje (np. nagrywanie dla uczniów piosenek, zapraszanie gości online itp.), to o przedszkolach wspominano raczej tylko w kontekście technicznych i formalnych trudności ze sprawowaniem opieki nad dziećmi.

W badaniach prezentowanych w niniejszym tekście jednym z celów było poznanie postaw wobec kształcenia na odległość nauczycielek i nauczycieli wychowania przedszkolnego. Postawy odzwierciedlają stosunek ludzi do obiektu, określając ich pozytywne lub negatywne wartościowania tego obiektu (Wojciszke i Doliński, 2011) i ujawniają się w przekonaniach, emocjach oraz zamierzonych zachowaniach (Myers, 2003). Określenie czyjejś postawy oznacza umiejscowienie człowieka na dwubiegunowym kontinuum wartościowania od stosunku skrajnie negatywnego do skrajnie pozytywnego (Wojciszke i Doliński, 2011). Poznanie postaw nauczycielek i nauczycieli wychowania przedszkolnego pozwoliło więc poznać ich opinie na temat kształcenia na odległość w czasie pandemii, deklarowane działania podejmowane w tym czasie oraz emocje, jakich doświadczali w pracy zdalnej.

W badaniu dokonałyśmy eksploracji związku pomiędzy postawami a psychologicznym dobrostanem nauczycielek/li wychowania przedszkolnego, wybierając jako narzędzie badawcze skalę prosperowania SP, która przeznaczona jest do badania dobrostanu eudajmonistycznego. W literaturze przedmiotu dobrostan konceptualizowany jest w odniesieniu do hedonii i eudajmonii (Kashdan i in., 2008). Dobrostan hedonistyczny reprezentowany jest przez subiektywną teorię dobrostanu, która wyjaśnia komponenty poznawcze dotyczące zadowolenia z życia i afektywne związane z bogactwem pozytywnych emocji i brakiem emocji negatywnych. Dobrostan eudajmonistyczny reprezentuje natomiast realizację własnego potencjału poprzez proces odkrywania siebie, poczucie celu i sensu życia, intensywne zaangażowanie w działania (Bojanowska i in., 2020). W tym drugim rozumieniu dobrostan jest zazwyczaj uznawany za pewną względnie stałą ocenę siebie tylko w niewielkim stopniu zależną od okoliczności, kształtuje się bowiem w wyniku wieloetapowego procesu, który prowadzi od wydarzeń, jakich doświadcza jednostka, poprzez reakcje emocjonalne i wspomnienia emocji do globalnego sądu o życiu (Kaczmarek, 2016). O dobrostanie eudajmonistycznym zwykle mówi się więc jako o zasobie, potencjale, który przybiera w miarę stałą wartość dla każdej osoby, a wydarzenia życiowe i kryzysy zmniejszają lub zwiększają go w niewielkim stopniu albo zmieniają, ale krótkotrwale (Ilska i Kołodziej-Zaleska, 2018). Znaczenie może mieć też charakter

\footnotetext{
${ }^{2}$ https://polskatimes.pl/koronawirus-dzieci-moga-byc-tajnymi-nosicielami-sarscov2-moga-sie-zarazic-ale-nie-wykazuja-objawow-choroby/ar/c1-14831020 (dostęp: 12.09.2020).

${ }^{3}$ https://www.polsatnews.pl/wiadomosc/2020-05-26/koronawirus-przybywa-ognisk-w-zlobkach-i-przedszkolach/ (dostęp: 12.09.2020).
} 
kryzysu - te nienormatywne, w których mamy do czynienia z zupełną utratą bilansu między zasobami a wyzwaniem, mają szansę obniżyć dobrostan na stałe lub chwilowo, ale w dużym stopniu (Ilska i Kołodziej-Zaleska, 2018). Zgodnie z ideą adaptacji do pewnego stopnia możemy dopasowywać się do złych zdarzeń, ale te wydarzenia nie muszą zmieniać ogólnego poczucia dobrostanu (Diner i in., 1999). Wysoki dobrostan może natomiast przekładać się na funkcjonowanie w różnych sytuacjach, także kryzysowych, i wpływać na przejawiane zaangażowanie, w tym na pracę zawodową (Niśkiewicz, 2016). Co istotne, z potencjału wynikającego z wysokiego dobrostanu można korzystać w mniejszym lub większym stopniu. Wykorzystaniu tego zasobu sprzyja odkrywanie siebie, intensywne zaangażowanie w różne działania, podejmowanie wyzwań i wysiłku (Bojanowska i in., 2020). Obecnie dostępne dane mimo wcześniejszych założeń o względnej stałości dobrostanu wskazują, że pandemia miała wpływ na well-being zarówno hedonistyczny, jak i eudajmonistyczny, powodując jego spadek. Warto jednak podkreślić, że różna była siła i dynamika zmian. Najmniejsze zmiany dotyczyły dobrostanu eudajmonistycznego, a największe hedonistycznego. Prowadzone analizy wykazały, że na przykład zadowolenie z życia spadło dopiero po czterech tygodniach blokady, ale nie zaobserwowano takiego spadku w pierwszych dwóch tygodniach. Natomiast najwyższy poziomu negatywnego afektu miał miejsce po dwóch tygodniach od zamknięcia, a następnie dwa tygodnie później ten negatywny wpływ zaczął spadać. Zaobserwowano także zmianę w osobistych wartościach uczestników badania, które odzwierciedlały zewnętrzne naciski na ograniczenie aktywności hedonistycznej (Bojanowska i in., 2020).

Będąc świadome kontrowersji dotyczących stałości/zmienności dobrostanu jednostki w sytuacji znaczących zmian życiowych, uznałyśmy, że dobrostan eudajmonistyczny może stanowić zasób do radzenia sobie z kryzysem (a nie, że sam kryzys będzie w pełni determinować dobrostan jednostki). Także w literaturze dotyczącej pandemii podkreśla się, że to ludzie i ich zasoby są rozwiązaniem kryzysu, a nie problemem, którym należy się zająć i skontrolować (Jetten i in., 2020). Projektując badanie, założyłyśmy zatem, że postawy nauczycielek przedszkola wobec kształcenia zdalnego mogą różnicować własne zasoby, które pozwalają przezwyciężać niedogodności związane z wykonywaniem trudnej, niedocenianej pracy, a do tego w kryzysowych warunkach.

\section{Metody}

\section{Cel badania}

Celem prowadzonych badań było: 1) zbadanie postaw wobec kształcenia na odległość w czasie pandemii COVID-19 i 2) eksploracja zależności pomiędzy dobrostanem nauczycielek/li wychowania przedszkolnego a postawami wobec kształcenia na odległość w czasie pandemii COVID-19. 


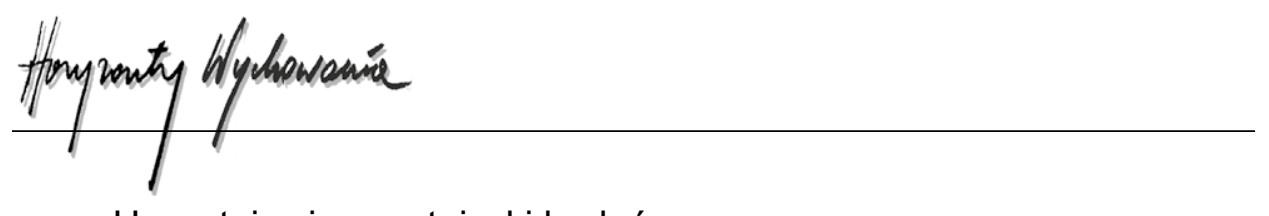

\section{Uczestnicy i uczestniczki badań}

Badaniami objęto 429 osób (427 kobiet i 2 mężczyzn). Większość badanych pracowało w zawodzie powyżej 11 lat (186 osób, 43,36\%), 83 osoby (19,35\%) pracowały 6-10 lat, 106 osób (24,71\%) 2-5 lat i 54 osoby (12,59\%) krócej niż 2 lata. Najwięcej wśród badanych było nauczycielek/li posiadających stopień nauczyciela kontraktowego 161 osób (37,53\%), ponadto wśród badanych było 113 nauczycieli dyplomowanych $(26,43 \%), 94$ nauczycieli mianowanych $(21,91 \%)$ i 61 nauczycieli stażystów $(14,22 \%)$. Większość nauczycielek/li pracowała w przedszkolu (368 osób, 85,5\%), a 46 osób w oddziale przedszkolnym w szkole $(10,72 \%)$, w innej placówce 4 osoby $(1,22 \%)$, natomiast 11 nauczycielek/li w więcej niż jednym rodzaju placówek (2,56\%). Miejscem pracy badanych były głównie przedszkola publiczne (355 osób, 82,75\%), rzadziej niepubliczne (64, 14,92\%), a 10 nauczycielek/li pracowało w więcej niż jednym rodzaju placówek (2,56\%). Były to głównie przedszkola/oddziały ogólnodostępne (364 osób, $84,85 \%$ ), następnie integracyjne (37, 8,62\%), specjalne (17, 3,96\%), a 11 nauczycielek/li pracowało w więcej niż jednym rodzaju placówek (2,56\%). Większość przedszkoli, w których pracowali badani zlokalizowanych było w miastach (345 osób, 80,42\%), 81 osób pracowało na wsi (18,88\%), a 3 osoby pracowały w więcej niż jednym rodzaju placówek ze względu na ich lokalizację (0,7\%). Respondentki/ci pracowały/li z grupami: 3-latków (60 osób, 13,99\%), 4-latków (77 osób, 17,95\%), 5-latków (56 osób, 13,05\%), 6-latków (78 osób, 18,18\%), mieszanymi ze względu na wiek (127 osób, 29,6\%), w więcej niż jednej grupie (31 osób, 7,23\%). Dobór do grupy badanej był celowy (nauczycielki/le wychowania przedszkolnego prowadzący zajęcia zdalne) i ochotniczy.

\section{Przebieg badania}

Etap selekcyjny. Do badań kwalifikowane/ni były/li nauczycielki/le wychowania przedszkolnego prowadzące/y zajęcia zdalne. Ankieta dostępna była od 15 do 30 czerwca 2020 roku na portalu społecznościowym Facebook, na stronach: Ja Nauczyciel'ka, Rok Relacji w Edukacji, Sylwia Jaskulska - Spotkania edukacyjne, Kreatywne Nauczycielki Przedszkola, Nauczycielka Przedszkola, Wczesnoszkolne i przedszkolne inspiracje, WychowaniePrzedszkolne.pl, JA.nauczycielka oraz innych i wielokrotnie udostępniona przez użytkowników i użytkowniczki portalu, a także rozsyłana drogą mailową do przedszkoli.

Etap właściwy polegał na anonimowych badaniach kwestionariuszowych online. Kwestionariusz składał się z metryczki, części dotyczącej postaw wobec kształcenia zdalnego (12 pytań), skali prosperowania (8 pytań) i jednego pytania otwartego. $\mathrm{Na}$ początku kwestionariusza były umieszczone informacje o tym, do kogo jest on kierowany (do czynnych zawodowo nauczycielek i nauczycieli wychowania przedszkolnego prowadzących zajęcia zdalne), o celu badania, czasie jego trwania, prawach uczestników badań, takich jak: informacje o tym, że badanie jest anonimowe, dobrowolne i że w każdym momencie można się z niego wycofać bez podawania powodu, a wszystkie 
podane informacje są poufne oraz że drogą e-mailową można zadawać pytania dotyczące roli respondenta. Podany był także kontakt mailowy do prowadzących badanie. Na końcu zaproszenia podana była informacja, że jeśli wyraża się zgodę na uczestnictwo, należy przejść do pytań właściwych.

Etap opracowania wyników polegał na ich analizie statystycznej (przy użyciu pakietu statystycznego SPSS) oraz interpretacji.

\section{Operacjonalizacja zmiennych}

Dobrostan określany był za pomocą skali prosperowania SP, która składa się z 8 stwierdzeń. Można się z nimi zgodzić lub nie, korzystając ze skali od 1 do 7 . Pytania dotyczą poczucia sensu życia oraz poczucia własnych kompetencji i atrybutów, np. „Prowadzę życie, które ma sens i cel”, „Aktywnie przyczyniam się do szczęścia i dobrostanu innych". Jak wskazują wskaźniki zgodności wewnętrznej, narzędzie ma wysoką rzetelność (alfa Cronbacha wynosi 0,899).

Postawy nauczycieli wobec kształcenia zdalnego badane były przy użyciu autorskiego kwestionariusza zawierającego 12 par stwierdzeń (po 4 pary do każdego z komponentów postawy - poznawczego, afektywnego, behawioralnego). Korzystając ze skali od 1 do 7 , respondenci wskazywali, w jakim stopniu się z nimi zgadzają.

\section{Analiza}

Użyto testu t Studenta dla prób zależnych do porównywania dwóch średnich pochodzących z jednej grupy: średniej wyniku w skali postaw (w odniesieniu do 12 aspektów postawy i postawy jako całości) oraz średniej skali psychospołecznego prosperowania.

\section{Wyniki i dyskusja}

\section{Postawy nauczycielek i nauczycieli wychowania przedszkolnego wobec kształcenia na odległość}

Badając postawy, określiłyśmy ich trzy komponenty: poznawczy, behawioralny i emocjonalny. Najniższe średnie opisują pierwszy z nich - nauczycielki uważają, że w trybie kształcenia na odległość prawie niemożliwa jest realizacja działań w zakresie wspierania społecznego rozwoju dziecka, w niewielkim zakresie widzą taką możliwość w zakresie rozwoju fizycznego, emocjonalnego, lecz zdecydowanie wyższym poznawczego. Kształcenie zdalne pozwoliło nauczycielkom na rozwój ich zawodowych kompetencji i nie przysparzało im trudności, choć raczej nie miały z nim wcześniej kontaktu. Nauczycielki 


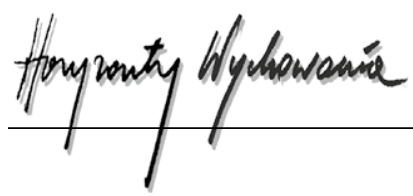

deklarowały też odczuwanie raczej pozytywnych emocji w relacjach z dziećmi i ich rodzicami oraz poczucie wsparcia dyrekcji placówki.

Tabela 1

Postawy nauczycieli wobec kształcenia na odległość w czasie pandemii COVID-19

\begin{tabular}{|c|c|c|c|c|}
\hline Postawy wobec kształcenia na odległość & Max & Min. & M & SD \\
\hline $\begin{array}{l}\text { Czyni niemożliwą realizację z powodzeniem działań w zakresie } \\
\text { wspierania fizycznego rozwoju dziecka/ } \\
\text { Umożliwia realizację z powodzeniem działań w zakresie wspierania } \\
\text { fizycznego rozwoju dziecka }\end{array}$ & 7 & 1 & 3,48 & 1,557 \\
\hline $\begin{array}{l}\text { Czyni niemożliwą realizację z powodzeniem działań w zakresie } \\
\text { wspierania emocjonalnego rozwoju dziecka/ } \\
\text { Umożliwia realizację z powodzeniem działań w zakresie wspierania } \\
\text { emocjonalnego rozwoju dziecka }\end{array}$ & 7 & 1 & 3,07 & 1,484 \\
\hline $\begin{array}{l}\text { Czyni niemożliwą realizację z powodzeniem działań w zakresie } \\
\text { wspierania społecznego rozwoju dziecka/ } \\
\text { Umożliwia realizację z powodzeniem działań w zakresie wspierania } \\
\text { społecznego rozwoju dziecka }\end{array}$ & 7 & 1 & 2,65 & 1,501 \\
\hline $\begin{array}{l}\text { Czyni niemożliwą realizację z powodzeniem działań w zakresie } \\
\text { wspierania poznawczego rozwoju dziecka/ } \\
\text { Umożliwia realizację z powodzeniem działań w zakresie wspierania } \\
\text { poznawczego rozwoju dziecka }\end{array}$ & 7 & 1 & 4,5 & 1,632 \\
\hline $\begin{array}{l}\text { Przysparza mi trudności/ } \\
\text { Nie przysparza mi trudności }\end{array}$ & 7 & 1 & 4,56 & 1,671 \\
\hline $\begin{array}{l}\text { Ogranicza rozwój moich kompetencji zawodowych/ } \\
\text { Pozwala mi rozwijać kompetencje zawodowe }\end{array}$ & 7 & 1 & 4,74 & 1,586 \\
\hline $\begin{array}{l}\text { Jest mi obce - nigdy nie wdrażałem/am jego elementów w mojej pracy/ } \\
\text { Nie jest mi obce - wdrażałem/am już jego elementy w mojej pracy }\end{array}$ & 7 & 1 & 3,21 & 1,943 \\
\hline $\begin{array}{l}\text { Na pewno nie wykorzystam go w pracy w przyszłości, jeśli nie będzie } \\
\text { znów takiej konieczności/ } \\
\text { Na pewno wykorzystam je w pracy w przyszłości// }\end{array}$ & 7 & 1 & 4,03 & 2,067 \\
\hline $\begin{array}{l}\text { Wyzwala we mnie negatywne emocje/ } \\
\text { Wyzwala we mnie pozytywne emocje }\end{array}$ & 7 & 1 & 3,85 & 1,617 \\
\hline $\begin{array}{l}\text { Sprawia, że odczuwam negatywne emocje w relacjach z dziećmi/ } \\
\text { Sprawia, że odczuwam pozytywne emocje w relacjach z dziećmi }\end{array}$ & 7 & 1 & 4,75 & 1,523 \\
\hline $\begin{array}{l}\text { Sprawia, że odczuwam negatywne emocje w relacjach z rodzicami/ } \\
\text { opiekunami dzieci, z którymi pracuję/ } \\
\text { Sprawia, że odczuwam pozytywne emocje w relacjach z rodzicami/ } \\
\text { opiekunami dzieci, z którymi pracuję }\end{array}$ & 7 & 1 & 4,64 & 1,566 \\
\hline $\begin{array}{l}\text { Sprawia, że odczuwam brak wsparcia ze strony dyrekcji przedszkola/ } \\
\text { Sprawia, że odczuwam wsparcie ze strony dyrekcji przedszkola }\end{array}$ & 7 & 1 & 4,26 & 1,951 \\
\hline Postawa & 7 & 1 & 3,99 & 1,072 \\
\hline
\end{tabular}

Źródło: opracowania własne

Ogólna średnia dla postawy wobec kształcenia na odległość to 3,99 (min. 1, max 7). Najbardziej pozytywne opinie dotyczyły rozwoju własnych kompetencji zawodowych, odczuwania pozytywnych emocji w relacji z dziećmi i ich rodzicami/opiekunami. Jednymi 
z najgorzej ocenianych obszarów były te związane z możliwością wspierania rozwoju społecznego i emocjonalnego dzieci oraz znajomości edukacji zdalnej. Postawy nauczycielek i nauczycieli wychowania przedszkolnego wobec kształcenia na odległość bliskie są wartości przeciętnej - 4. Nauczycielki i nauczyciele nie mają więc jednoznacznych postaw wobec takiej formy edukacji lub ich postawy są ambiwalentne. Ogólną średnią zaniżają głównie elementy postawy dotyczące komponentu poznawczego, a więc przekonań na temat możliwości pracy z małymi dziećmi na odległość. Tendencje te są podobne do uzyskanych we wcześniejszych badaniach poświęconych postawom nauczycielek i nauczycieli pracujących w szkołach różnych szczebli, którzy również nie byli przekonani co do możliwości realizacji z powodzeniem podstawowych funkcji szkoły, takich jak wychowanie i opieka, uznawali jednak, że jest możliwa realizacja funkcji edukacyjnej szkoły (Jaskulska i Jankowiak, 2020). Uzyskane dane wskazują, że nauczycielki i nauczyciele wychowania przedszkolnego mimo podjętego wyzwania kształcenia na odległość uznali swoją aktywność za wymuszoną sytuacją, co spowodowało, że podejmowane działania nie ukształtowały ich przekonania do tej formy pracy z małymi dziećmi.

\section{Dobrostan a postawy wobec kształcenia na odległość}

Do oceny dobrostanu nauczycielek i nauczycieli wychowania przedszkolnego użyto Skali Prosperowania, która składała się z ośmiu stwierdzeń, do których odnosili się badani: prowadzę życie, które ma sens i cel; moje relacje społeczne są wspierające i dają mi satysfakcję; angażuję się i interesuję tym, czym zajmuję się na co dzień; aktywnie przyczyniam się do szczęścia i dobrostanu innych; jestem kompetentny i zdolny do wykonywania zajęć, które są dla mnie ważne; jestem dobrym człowiekiem i prowadzę dobre życie; z optymizmem patrzę na swoją przyszłość; ludzie mnie szanują. Średnia odpowiedzi respondentek i respondentów to 6,04312 (min. 1, max. 7) przy odchyleniu standardowym SD =0,805640. Jest to minimalnie wyższa średnia od tej, którą uzyskali w pierwszej części badania nauczyciele i nauczycielki pracujący w szkołach (Jaskulska i Jankowiak, 2020). Uzyskane wyniki wskazują więc, że dobrostan nauczycielek i nauczycieli wychowania przedszkolnego jest dosyć wysoki. Postanowiono sprawdzić, czy istnieje związek pomiędzy dobrostanem a postawami wobec kształcenia na odległość (tabela 2). 


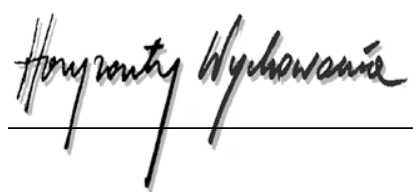

Tabela 2

Dobrostan a postawy wobec kształcenia na odległość w czasie pandemii COVID-19

\begin{tabular}{|l|c|c|c|}
\hline \multicolumn{1}{|c|}{ Postawy wobec kształcenia na odległość } & N & Test T & P \\
\hline $\begin{array}{l}\text { Czyni niemożliwą realizację z powodzeniem działań w zakresie wspierania } \\
\text { fizycznego rozwoju dziecka/ } \\
\text { Umożliwia realizację z powodzeniem działań w zakresie wspierania } \\
\text { fizycznego rozwoju dziecka }\end{array}$ & 428 & $-31,518$ & 0,000 \\
\hline $\begin{array}{l}\text { Czyni niemożliwą realizację z powodzeniem działań w zakresie wspierania } \\
\text { emocjonalnego rozwoju dziecka/ } \\
\text { Umożliwia realizację z powodzeniem działań w zakresie wspierania } \\
\text { emocjonalnego rozwoju dziecka }\end{array}$ & 428 & $-37,202$ & 0,000 \\
\hline $\begin{array}{l}\text { Czyni niemożliwą realizację z powodzeniem działań w zakresie wspierania } \\
\text { społecznego rozwoju dziecka/ } \\
\text { Umożliwia realizację z powodzeniem działań w zakresie wspierania } \\
\text { społecznego rozwoju dziecka }\end{array}$ & 428 & $-41,985$ & 0,000 \\
\hline $\begin{array}{l}\text { Czyni niemożliwą realizację z powodzeniem działań w zakresie wspierania } \\
\text { poznawczego rozwoju dziecka/ } \\
\text { Umożliwia realizację z powodzeniem działań w zakresie wspierania } \\
\text { poznawczego rozwoju dziecka }\end{array}$ & 428 & $-17,974$ & 0,000 \\
\hline $\begin{array}{l}\text { Przysparza mi trudności/ } \\
\text { Nie przysparza mi trudności }\end{array}$ & 428 & $-17,307$ & 0,000 \\
\hline $\begin{array}{l}\text { Ogranicza rozwój moich kompetencji zawodowych/ } \\
\text { Pozwala mi rozwijać kompetencje zawodowe }\end{array}$ & 428 & $-16,369$ & 0,000 \\
\hline $\begin{array}{l}\text { Jest mi obce - nigdy nie wdrażałem/am jego elementów w mojej pracy/ } \\
\text { Nie jest mi obce - wdrażałem/am już jego elementy w mojej pracy }\end{array}$ & 428 & $-29,343$ & 0,000 \\
\hline $\begin{array}{l}\text { Na pewno nie wykorzystam go w pracy w przyszłości, jeśli nie będzie znów } \\
\text { takiej konieczności/ } \\
\text { Na pewno wykorzystam je w pracy w przyszłości/ }\end{array}$ & 428 & $-19,827$ & 0,000 \\
\hline $\begin{array}{l}\text { Wyzwala we mnie negatywne emocje/ } \\
\text { Wyzwala we mnie pozytywne emocje }\end{array}$ & 428 & $-26,945$ & 0,000 \\
\hline $\begin{array}{l}\text { Sprawia, że odczuwam negatywne emocje w relacjach z dziećmi/ } \\
\text { Sprawia, że odczuwam pozytywne emocje w relacjach z dziećmi }\end{array}$ & 428 & $-16,637$ & 0,000 \\
\hline $\begin{array}{l}\text { Sprawia, że odczuwam negatywne emocje w relacjach z rodzicami/ } \\
\text { opiekunami dzieci, z którymi pracuję/ } \\
\text { Sprawia, że odczuwam pozytywne emocje w relacjach z rodzicami/ } \\
\text { opiekunami dzieci, z którymi pracuję }\end{array}$ & 428 & $-18,164$ & 0,000 \\
\hline $\begin{array}{l}\text { Sprawia, że odczuwam brak wsparcia ze strony dyrekcji przedszkola/ } \\
\text { Sprawia, że odczuwam wsparcie ze strony dyrekcji przedszkola }\end{array}$ & 428 & $-18,432$ & 0,000 \\
\hline
\end{tabular}

Źródło: opracowania własne

Uzyskano wyniki świadczące o tym, że im wyższy poziom dobrostanu, tym wyższe średnie postaw, zatem tym lepiej nauczycielki oceniają poszczególne elementy ich rzeczywistości w czasie edukacji zdalnej. Wyższy dobrostan jest w korelacji nie tylko z tymi komponentami postaw, które wypadły w badaniu najlepiej, ale też z tymi, które wskazują na największe deficyty funkcjonowania przedszkoli w czasie pandemii. Wysoki dobrostan jest zatem związany z dostrzeganiem możliwości wspierania fizycznego, emocjonalnego, poznawczego i społecznego rozwoju dziecka, rzutuje na odczuwanie mniejszego zakresu trudności związanych z kształceniem zdalnym (lub skuteczniejszego ich pokonywania), 
pozwala dostrzec rozwój własnych kompetencji zawodowych, ma związek z częstszym wykorzystywaniem elementów kształcenia zdalnego w przeszłości i planowaniem wykorzystania go w przyszłości, a także odczuwaniem pozytywnych emocji w relacjach z ludźmi, którzy wraz z nauczycielkami tworzą społeczność danego przedszkola.

Ogólnie rzecz biorąc, dobrostan badanej przez nas grupy nauczycieli jest wysoki, co wskazuje, że być może właśnie w zasobach osobistych należy szukać odpowiedzi na pytanie o źródła pozwalające radzić sobie w zawodzie, wobec którego są stawiane wysokie wymagania przy jednoczesnym niewielkim prestiżu społecznym. Należałoby zbadać dobrostan tej grupy i sposoby radzenia sobie w czasie względnej stabilizacji (po pandemii), co mogłoby dać odpowiedź na pytanie, czy rzeczywiście jest to ważny czynnik radzenia sobie w pracy nauczycielki przedszkola, czy też jego siła ujawnia się tylko w sytuacji trudnej.

Przyjmuje się, że dobrostan jest zasobem o względnie stałej wartości i raczej pomaga w radzeniu sobie w sytuacjach trudnych, niż jest przez nie zmieniany (ewentualnie czasowo, raczej nie na stałe). Z dotychczasowych badań nad dobrostanem wynika, że często jego największa ekspresja występuje właśnie w momencie kryzysu (Ryff, 2014, 2017). Dlatego też wydaje się istotne tworzenie w placówkach edukacyjnych klimatu sprzyjającego wykorzystaniu zasobów dobrostanu, a także kierunków rozwoju zawodowego nauczycielek/li wychowania przedszkolnego. Przykładem takich działań jest job crafting, czyli przekształcanie pracy. W koncepcji tej zakłada się, że każdy pracownik może dokonywać choćby minimalnych zmian w swojej pracy, które sprawią, że będzie bardziej zadowolony i efektywniejszy, a praca nabierze dla niego więcej sensu. Pracownik może na przykład tak organizować pracę, aby wykorzystywać w niej swoje mocne strony, wzmacniać pozytywne relacje, dostrzegać społeczną użyteczność własnych zawodowych poczynań (Łądka-Barańska i in., 2018). W interwencjach w duchu job craftingu, na przykład szkoleniach dla pracowników, odchodzi się od zapobiegania negatywnym skutkom przeciążenia pracą (wypalenie zawodowe) na rzecz wzmacniania potencjału pracowników i wykorzystywania przez nich ich zasobów, w tym dobrostanu (Łądka-Barańska i in., 2018). Być może badane nauczycielki i nauczyciele wychowania przedszkolnego charakteryzujący się wysokim dobrostanem aktywnie zmodyfikowali swoją pracę zdalną tak, aby dostrzegać w niej większy sens i odczuwać z niej większe zadowolenie, bowiem związek postaw wobec wyzwań kształcenia zdalnego i dobrostanu wskazuje, że osoby o większych zasobach radziły sobie w nowej rzeczywistości lepiej.

\section{Konkluzja}

Założenie o związku uogólnionego dobrostanu z postawami nauczycielek wychowania przedszkolnego wobec kształcenia zdalnego okazało się słuszne. Zasób ten przekłada się na myślenie o kształceniu na odległość, jego percepcję oraz działania i emocje z nim związane. Jest to wynik zgodny z innymi badaniami, na przykład nad związkiem 


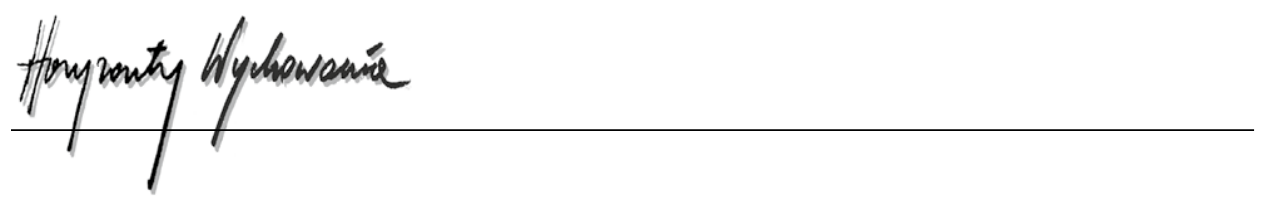

dobrostanu i zaangażowania w pracę (Baka, 2013). Im większy dobrostan, tym to zaangażowanie większe.

Zawód nauczyciela wychowania przedszkolnego powinien być wzmacniany zewnętrznie (na przykład poprzez promowanie w mediach szczególnie zaangażowanych w tę pracę osób i ich osiągnięć) oraz wewnętrznie poprzez wykorzystywanie osobistych zasobów nauczycielek/li do kreowania środowiska pracy.

\section{BIBLIOGRAFIA}

Alezra, F. (2019). The image of kindergarten teacher in the Israeli media. Rocznik Pedagogiczny 42, 165-180.

Baka, Ł. (2013). Pracoholizm i zaangażowanie w pracy jako wyznaczniki dobrostanu psychicznego pracowników. W: Z. Runak i B. Zmyślona (red.), Jakość życia a zrównoważony rozwój (s. 9-26). Wrocław: Wydawnictwo Uniwersytetu Ekonomicznego we Wrocławiu.

Bojanowska, A., Kaczmarek, L.D., Kościelniak, M. i Urbańska, B. (2020). Values and well-being change amidst the COVID-19 pandemic in Poland. https://doi.org/10.31234/osf.io/xr87s

Centrum Cyfrowe. (2020). Badanie edukacji zdalnej w czasie pandemii. https://centrumcyfrowe. pl/edukacja-zdalna/

Diener, E., Suh, E.M., Lucas, R.E. i Smith, H.L. (1999). Subjective well-being: Three decades of progress. Psychological Bulletin 125(2), 276-302.

He, F., Deng, Y. i Li, W. (2020). Coronavirus Disease 2019 (COVID-19): What we know? Journal of Medical Virology 7(92), 719-725.

Heald-Sargent, T., Muller, W.J., Zheng, X., Rippe, J., Patel, A.B. i Kociolek, L.K. (2020). Age-related differences in nasopharyngeal severe acute respiratory syndrome coronavirus 2 (SARS-CoV-2) levels in patients with mild to moderate coronavirus disease 2019 (COVID-19). JAMA Pediatrics 174(9), 902-903.

Ilska, M. i Kołodziej-Zaleska, A. (2018). Dobrostan hedonistyczny i eudajmonistyczny w sytuacjach kryzysów normatywnych i nienormatywnych. Zeszyty Naukowe Politechniki Śląskiej. Seria: Organizacja i Zarządzanie 123, 155-184.

Jaskulska, S. i Jankowiak, B. (2020). Dobrostan nauczycielek i nauczycieli a ich postawy wobec kształcenia odległość w czasie pandemii COVID-19. Przegląd Pedagogiczny 1, 219-232.

Jaskulska, S. i Jankowiak, B. (2020). Postawy nauczycielek i nauczycieli wobec kształcenia odległość w czasie pandemii COVID-19. Studia Edukacyjne 57, 47-65.

Jetten, J., Reicher, S.D., Haslam, S.A. i Cruwys, T. (2020). Together apart: The psychology of COVID-19. New York: SAGE Publications.

Kaczmarek, Ł.D. (2016). Pozytywne interwencje psychologiczne. Dobrostan a zachowania intencjonalne. Poznań: Zysk i S-ka.

Kashdan, T., Biswas-Diener, R. i King, L. (2008). Reconsidering happiness: The costs of distinguishing between hedonics and eudaimonia. Journal of Positive Psychology 3(4), 219-233. doi:10.1080/17439760802303044

Kuszak, K. (2020). Paradoks: Nauczyciel(ka) przedszkola - profesja społecznie ważna o niskim poziomie prestiżu. Czas Kultury 1, 57-66.

Łądka-Barańska, A., Puchalska-Kamińska, M. i Gałęzowska-Szomborg, E. (2018). Job Crafting. Jak samodzielne kształtowanie zmian w sposobie pracy zwiększa dobrostan i efektywność pracowników? Coaching Review 1(10), 237-251.

Myers, D.G. (2003). Psychologia społeczna. Poznań: Zysk i S-ka. 
Niśkiewicz, Z. (2016). Dobrostan psychiczny i jego rola w życiu człowieka. Studia Krytyczne 3, 139-151.

Ptaszek, G., Bigaj, M., Dębski, M., Pyżalski, J. i Stunża, G.D. (2020). Zdalna edukacja - gdzie byliśmy, dokąd idziemy? Wstępne wyniki badania naukowego „Zdalne nauczanie a adaptacja do warunków społecznych w czasie epidemii koronawirusa". https://ug.edu.pl/news/sites/ug.edu. pl.news/files/2020-06/Badanie\%20zdalnenauczanie_prezentacja_1.pdf

Ryff, C.D. (2014). Psychological well-being revisited: Advances in science and practice. Psychother Psychosomatic 83(1), 10-28. doi:10.1159/000353263 63

Ryff, C.D. (2017). Eudaimonic well-being, inequality, and health: Recent findings and future directions. International Review of Economic 64, 159-178.

Saltzman, L.Y., Hansel, T.C. i Bordnick P.S. (2020). Loneliness, isolation, and social support factors in post-COVID-19 mental health. Psychological Trauma: Theory, Research, Practice, and Policy 12, 55-57.

Wojciszke, B. i Doliński D. (2011). Psychologia społeczna. W: J. Strelau i D. Doliński (red.), Psychologia akademicka. Podręcznik (t. 2, s. 293-447). Gdańsk: GWP.

Zaród, M. (2020). Jak nauczyciele mogą zadbać obecnie o swój dobrostan? W: J. Pyżalski (red.), Edukacja w czasach pandemii wirusa COVID-19. Z dystansem o tym, co robimy obecnie jako nauczyciele (s. 81-85). Warszawa: EduAkcja.

\section{Copyright and License}

This article is published under the terms of the Creative Commons Attribution - NoDerivs (CC BY- ND 4.0) License http://creativecommons.org/licenses/by-nd/4.0/ 